\title{
Jejak Perkawinan Minangkabau dengan Tionghoa dalam Film Jangan Panggil Aku Cina dan Novel Mengurai Rindu
}

\section{Minangkabau-Chinese Marriage in "Jangan Panggil Aku Cina" Movie and "Mengurai Rindu” Novel}

\author{
Rifki Kurniawan, Silvia Rosa, Yerri Satria Putra \\ yerri@hum.unand.ac.id \\ Universitas Andalas
}

\begin{abstract}
ABSTRAK
This article is the comparative analysis result of the film "Jangan Panggil Aku Cina" and the novel "Mengurai Rindu" through intertextual studies.

The film "Jangan Panggil Aku Cina" and the novel "Mengurai Rindu" have three formulas of hypograms (1) expansion, found in conflict, character, and characterization, (2) conversion, found in the cast of Minangkabau and Chinese Ethnic figures and social status of the main character, (3) Modifications or changes, found in the "Mengurai Rindu" about the rejection of mamak over the future husband, and the way of the main character deals with mamak's rejection.
\end{abstract}

Keywords: Jangan Panggil Aku Cina, Mengurai Rindu, Intertekstual, Hypograms.

\section{PENGANTAR}

Film Jangan Panggil Aku Cina (JPAC) garapan sutradara Doddy Djanas merupakan salah satu karya seni yang berbentuk film. Film ini tayang pertama kali tahun 2002. Film ini bercerita tentang percintaan Olivia dengan Yusril. Olivia adalah seorang gadis keturunan Tionghoa yang berdomisili di daerah Pondok,Kota Padang, sedangkan Yusril adalah seorang pemuda pribumi yang berasal dari daerah Pariaman. Yusril adalah seorang dokter yang jatuh cinta kepada Olivia. Kedua insan muda ini ingin segera untuk menikah. Akan tetapi rencana mereka ditolak habis-habisan oleh keluarga besar Yusril. Kaum kerabat Yusril berpandangan bahwa menikah dengan orang keturunan Tionghoa merupakan aib besar bagi keluarga Yusril. Keluarga Yusril menganut prinsip yang sesuai dengan adat Minangkabau yang memandang bahwa pernikahan yang ideal adalah pernikahan satu kampung namun berbeda suku, tujuannya agar seorang mamak dapat dengan mudah membimbing kemenakannya dan sekaligus dekat dengan keluarga bako.

Perkawinan seperti inilah yang diinginkan oleh mamak Yusril, yakni dengan cara Menjodohkan Yusril dengan anak gadisnya. Konflik selanjutnya terjadi ketika Olivia dan keluarga mengetahui bahwa Yusril adalah lelaki Pariaman. Adat Pariaman menganut salah satu tradisi yang unik, yaitu tradisi uang japuik (uang jemputan). Tradisi uang japuik yang lazim berlaku di daerah Pariaman (Elvia, Anwar, \& Meigalia, 2018; Oktavia, 2011; Putra, 2016) juga dianut oleh keluarga Yusril. Pihak keluarga Yusril dengan berat hati mencoba menyetujui rencana pernikahan Yusril dengan Olivia, tetapi dengan meminta uang japuik yang sesuai dengan gelar dan jenis pekerjaan si calon mempelai pria. Keluarga Yusril dalam hal ini meminta uang japuik sebesar Rp40.000.000,-Sesungguhnya persyaratan yang diajukan oleh pihak keluarga Yusril ini adalah strategi untuk menggagalkan 
rencana pernikahan Yusril dengan Olivia. Namun keteguhan hati Yusril terhadap pilihannya meluluhkan hati mamaknya dan akhirnya menyetujui bahkan bersedia membiayai pernikahan Yusril dengan Olivia.

Sementara novel Mengurai Rindu (Syamsuddin, 2012) (yang selanjutnya ditulis MR) karya Nang Syamsuddin adalah bentuk dari seni sastra yang terbit pada tahun 2012. Novel ini berkisah tentang tokoh utama yang bernama Lela yang merantau ke kota Padang dan bekerja sebagai guru di SMA Don Bosco Padang. Ia jatuh cinta kepada seorang pemuda etnis Tionghoa yang bernama Gunawan. Kisah percintaan mereka ditentang oleh mamak Lela yaitu Angku Datuk. Penolakan dan pertentangan Angku Datuk tidak diindahkan oleh Lela karena sanak keluarga yang lain menyetujui pilihan Lela.

Bukan hanya Angku Datuk yang menolak hubungan Lela dengan pemuda Tionghoa tersebut, rekanrekan sesama guru di sekolahnya juga menyebar gosip atas pilihan Lela yang dianggap salah. Penolakan mereka semua didasarkan pada anggapan bahwa menikah dengan etnis Tionghoa merupakan kesalahan yang besar dalam adat Minangkabau.

Adat Minangkabau telah mengatur bahwa perkawinan yang ideal hendaknya dilakukan antar orang yang berbeda suku dalam nagari yang sama (endogami) (Asmaniar, 2018). Orang Minangkabau tidak memandang positif pelaksanaan perkawinan lintas etnis, apalagi dengan etnis Tionghoa. Hubungan pernikahan yang terjadi antar anggota kerabat dengan etnis non-Minang, seperti Jawa, Sunda, Batak saja sudah tidak diinginkan oleh kaum kerabat, apalagi dengan etnis Tionghoa. Oleh karena itu, apabila ada salah seorang anggota kerabat yang sempat membuat pilihan yang dianggap keliru itu, yaitu menikah dengan etnis Tionghoa, tentu akan menuai konflik yang tidak kunjung usai sepanjang usia perkawinannya. Persoalan seperti inilah yang dialami oleh Lela yang memutuskan untuk menikah dengan Gunawan yang tercermin dalam film JPAC.

Konflik yang terjadi bukan hanya tentang persoalan pilihan Lela, melainkan konflik terus berlanjut setelah Lela menikah dengan Gunawan. Lela yang kehidupannya sangat mapan bersama Gunawan tidak lagi mengurus dan memikirkan tentang keluarga matrilineal yang seharusnya menjadi tanggung jawabnya sebagai limpapeh rumah nan gadang. Perilaku Lela dan Gunawan membangun konflik makin pelik dengan keluarga besar Lela.

Novel MR dan film JPAC memaparkan persoalan perkawinan lintas budaya antara etnis Tionghoa yang tinggal di Padang dengan etnis Minangkabau. Fakta sastra dan cerita yang ditemukan dalam novel MR dan film JPAC ini unik dan menarik untuk diteliti. Keunikannya terletak pada persoalan yang berhubungan dengan perkawinan lintas etnis dan budaya yang terjadi dalam masyarakat Minangkabau. Secara tematik tergambar sebuah jejak yang berulang yang terkandung di dalam kedua karya seni yang berbeda genre ini. Jejak berulang yang secara tematik dibingkai oleh perkawinan lintas etnis dan budaya Tionghoa ini menarik apabila diurai dengan perspektif intertekstual.

Pradopo (Endraswara, 2003) menyatakan bahwa sebuah penelitian intertekstual merupakan usaha pemahaman sastra sebagai sebuah presupposition, yakni sebuah perkiraan suatu teks baru mengandung teks lain sebelumnya. Pemikiran teks baru mentransformasikan ke dalam karya sendiri dengan gagasan dan estetik sendiri sehingga terjadi perpaduan baru, hal ini dapat dilihat dengan membandingkan teks yang menjadi hipogram dengan teks transformasi. Berdasarkan asumsi tersebut kedua karya seni, yaitu novel dan film menarik untuk diteliti secara intertekstual terutama yang terkait dengan tematik perkawinan lintas etnis dan budaya. 


\section{KERANGKA TEORI DAN METODE}

Culler (Endraswara, 2003) menyatakan bahwa studi intertekstualitas akan membawa peneliti memandang teks-teks pendahulu sebagai sumbangan pada suatu kode yang memungkinkan efek signification, yaitu pemaknaan yang bermacam-macam. Melalui pemaknaan yang bermacam-macam akan ditemukan makna yang asli. Pada saat itu pula teks asli akan diketemukan yakni, teks yang kurang lebih disebut orisinal. Melalui studi interteks setidaknya peneliti akan mampu memilih dan memilah karya yang paling dekat dengan asli dan mana yang telah bergeser.

Menurut Teeuw (Teeuw, 1993) kajian intertekstualitas dimaksudkan sebagai kajian terhadap sejumlah teks kesastraan, yang diduga mempunyai bentuk-bentuk hubungan tertentu, misalnya untuk menemukan adanya hubungan unsur-unsur intrinsik seperti ide, gagasan, peristiwa, plot, penokohan, gaya bahasa dan lain-lain; di antara teks-teks yang dikaji. Secara lebih kritis, dapat dikatakan bahwa kajian intertekstualitas berusaha menemukan aspek-aspek tertentu yang telah ada pada karya-karya sebelumnya pada karya yang muncul lebih terdahulu.

Prinsip dasar intertekstual (Endraswara, 2003) adalah karya hanya dapat dipahami maknanya secara utuh dalam kaitannya dengan teks lain yang menjadi hipogram. Dalam kaitan ini sastrawan yang lahir berikut adalah reseptor dan transformator karya sebelumnya. Dengan demikian, mereka selalu menciptakan karya asli, karena dalam mencipta selalu diolah dengan pandangannya sendiri dengan horizon dan atau harapannya sendiri. Riffatere (dalam Sudikan, 2001) menjelaskan hipogram sebagai kata atau kelompok kata suatu sajak yang terlebih dahulu (preexistent word group), yang memperlihatkan hubungan antarteks, yang menjadi modal sajak yang lahir kemudian. Selanjutnya Hutomo (Sudikan, 2001) menyimpulkan hipogram sebagai unsur cerita baik berupa ide, kalimat, ungkapan ataupun peristiwa yang terdapat pada suatu teks pendahulu (teks transformasi atau teks yang dipengaruhinya).

Telaah intertekstual pernah dilakukan oleh Partini Sardjono Pradotokusumo yang didasarkan pada teori intertekstual ala Riffaterre dengan penerapan yang tidak seutuhnya sama dan didasarkan juga pada teori yang ia kembangkan sendiri dengan merumuskan hipogram meliputi(a) ekspansi, (b)konversi, (c) modifikasi dan (d) ekserp (Sudikan, 2001). Ekspansi diartikan sebagai perluasan atau pengembangan, dan mengubah unsur pokok matriks kalimat menjadi bentuk yang lebih kompleks. Lebih lanjut Pradotokusumo (dalam Sudikan, 2001) menjelaskan bahwa ekspansi berarti juga penambahan unsur yang semula sama sekali tidak ada. Penambahan ini biasanya dilakukan penulis karena tuntutan zaman atau karena penulis ingin berkreasi.

Konversi menurut Riffaterre (dalam Sudikan, 2001) adalah mengubah unsur-unsur kalimat matriks dengan memodifikasinya dengan sejumlah faktor yang sama. Pradotokusumo (dalam Sudikan, 2001) menyebutkan, bahwa konversi adalah pemutarbalikan hipogram atau matriksnya. Modifikasi dan ekserp adalah teori yang dikembangkan sendiri oleh Pradotokusumo dalam melihat hubungan intertekstual pada Kakawin Gajah Mada. Modifikasi yaitu perubahan tataran linguistik, dalam ranah sastra modifikasi ini pengarang bisa saja mengganti nama tokoh, latar tempat dan waktu. Ekserp diartikan sebagai inti sari dari unsur hipogram atau penyadapan inti sari dari hipogram. 
Objek pada penelitian ini adalah film "Jangan Panggil Aku Cina" dan novel Mengurai Rindu yang diterbitkan pada tahun 2012. Film JPAC merupakan garapan sutradara Doddy Djanas yang tahun 2002. Film ini dibagi ke dalam 2 episode, episode 1 dengan durasi waktu 00:47:49, dan episode 2 dengan durasi waktu 00:47:49.

Penelitian ini dianalisis menggunakan teori intertekstual, dengan itu pada film JPAC dilakukan pentranskripsian atau pengalihan wacana menjadi teks untuk mempermudah proses analisis. Dalam hal ini penulis menggunakan teknik pengalihan wacana lisan ke tulisan. Suripan Sadi Hutomo (dalam Sudikan, 2001) memberikan petunjuk dalam mentranskripsi dari wacana tulisan ke teks tulis, di antaranya melalui tahapan sebagai berikut:

1. Transkripsi secara kasar, artinya semua suara dalam rekaman dipindahkan ke tulisan tanpa mengindahkan tanda baca.

2. Transkripsi kasar tersebut selanjutnya disempurnakan. Hasil penyempurnaan dicocokkan kembali dengan rekaman.

3. Setelah transkripsi disempurnakan, peneliti menekuni hasil transkripsinya. Kata-kata dan kalimat yang kurang jelas diberi tanda baca dan tanda-tanda lain yang diperlukan.

4. Selanjutnya diketik (manual atau komputer).

Metode yang dilakukan dalam penelitian ini meliputi 2 tahap, yaitu tahap pengumpulan data dan tahap analisis data. Pada tahap pengumpulan data dilakukan tindakan sebagai berikut:

1. Menyaksikan film JPAC serta mentranskripsikan film JPAC ke dalam bentuk naskah.

2. Membaca novel MR secara cermat dan membuat sinopsis ceritanya.

Selanjutnya kedua karya seni ini diidentifikasi persamaan dan perbedaan unsur-unsur pembangun cerita (intrinsik) dan pada tahap analisis data dilakukan tindakan yang sesuai dengan tahap-tahap yang berlaku dalam mengaplikasikan teori intertekstual.

\section{HASIL DAN PEMBAHASAN}

Film JPAC garapan sutradara Doddy Djanas merupakan hipogram untuk novel MR. Hal ini terbukti karena adanya persamaan ide. Selain itu beberapa peristiwa yang terjadi dalam novel MR yang sudah lebih dahulu di ekspresikan oleh Doddy Djanas, kemudian ditransformasikan oleh Nang Syamsuddin pada novelnya yang berjudul Mengurai Rindu pada tahun2012 . Novel MR dipandang menyerap unsur-unsur film JPAC menjadi bagian ceritanya. Pada tataran struktur cerita hubungan interteks antara kedua cerita terjadi pada unsur penokohan, setting, alur yang di dalamnya termasuk jejak-jejak cerita.

\subsubsection{Ekspansi}

Film JPAC dan novel MR yang dibingkai secara tematik oleh perkawinan lintas budaya yang menjadikan film JPAC sebagai hipogram dan titik tolak pengembangan pada novel MR. Novel MR mengalami perluasan dari teks hipogramnya. Perluasan ini meliputi konflik, tokoh, dan keadaan tokoh.

Tokoh utama etnis Minangkabau pada Film JPAC dan novel MR memaparkan sosok dan peran seorang mamak yang berkeinginan menerapkan perkawinan ideal, namun tokoh Yusril (pada film) dan Lela (pada novel) 
menolak saran dari mamaknya. Tokoh Yusril dan Lela lebih memilih menikah dengan pilihannya sendiri yang sejatinya berasal dari kalangan Tionghoa. Penolakan tersebut memicu konflik perkawinan lintas budaya antara etnis Minangkabau dengan etnis Tionghoa.

Adat istiadat dibuat oleh masyarakat pemakainya untuk mengatur dan menata kehidupan pribadi dan bermasyarakat, begitu juga dengan adat Minangkabau. Adat Minangkabau mengatur baik dari segi berpakaian, sopan santun, kematian bahkan Mengenai perkawinan. Perkawinan yang dianjurkan di Minangkabau adalah perkawinan ideal. Perkawinan ideal merupakan suatu bentuk perkawinan yang sangat disarankan di Minangkabau. Perkawinan ideal salah satunya dengan melakukan perkawinan antarkeluarga terdekat, seperti kawin dengan anak mamak yang lazim disebut "pulang ka mamak" atau kawin dengan kemenakan ayah yang disebut "pulang ka bako" sebagai wujud dari "anak dipangku kamanakan dibimbiang”. Bentuk lainnya adalah perkawinan saling mengambil untuk mempererat besan beripar.

Perkawinan ideal berfungsi sebagai penangkal kerapuhan berumah tangga, hal ini berhubungan dengan peran antara suami dan istri. Masyarakat Minangkabau sangat hati-hati untuk kawin keluar wilayah hukum adat mereka, terutama bagi kaum laki-laki agar keturunan nanti tetap bersuku secara matrilineal. Hal inilah yang menjadi persepsi dari mamak Yusril Bagindo Sulaiman. Bagindo Sulaiman sangat berkeinginan untuk menjodohkan kemenakannya dengan anak perempuannya Ana.

Di ruang tamu rumah Mamak Yusril. Mamak sedang membaca koran dan dihampiri oleh Mak Tuo.

Mak Tuo : Ini pendapat saya $D a$.

Mamak : Apo tu?

Mak Tuo : Bagaimana Yusril kita jodohkan dengan Ana?

Mamak : Iyo.. itu juo nan tapikia dek uda, sia lah nan patuik untuaknyo manikah.

Mak Tuo : Bukan lagi patut, tapi sudah seharusnya, karena umur Ana kan lebih dari tiga puluh tahun.

Mamak : (mengangguk) Yolah bisuak uda sampaikan ke si Rosma.

Mak Tuo : Yaaa... awak pulang ka bako Da (beranjak pergi meninggalkan suaminya).

Lain halnya pada novel MR, Yusril menolak perjodohan yang direncanakan mamaknya, ia lebih memilih gadis Tionghoa yang bernama Olivia. Akan tetapi pilihannya ini ditolak oleh keluarga matrilinealnya terutama mamak Bagindo Sulaiman. Penolakan ini berdasarkan perbedaan etnis dan perbedaan agama. Adat Minangkabau yang berfalsafah adat basandi syarak, syarak basandi kitabullah, falsafah ini secara tidak langsung mengatakan bahwa setiap orang Minangkabau adalah Islam. Dalam hal perkawinan faktor agama sangat penting yaitu perkawinan seiman, namun kenyataannya Olivia adalah nonmuslim. Berikut kutipan pada film.

Di rumah Yusril, Rosma masuk ke kamar Yusril.

Rosma : Baru pulang Ril?

Yusril : Iyo.

Rosma : Tadi Mak Tuo mu kamari, dia menanyakan tentang foto itu.

Yusril : Mungkin begitu lebih baik.

Rosma : Besok mamakmu yang akan ke sini, ntah apa yang akan mak jelaskan

Yusril : Kita harus belajar untuk jujur dengan hati kita mak

Rosma : Kamu serius dengan Olivia? (berpindah duduk, lebih dekat dengan Yusril)

Yusril : Serius mak

Rosma : Baa jo agamonyo?

Yusril : Bukankah sepatutnya perempuan itu harus mengikuti suaminya mak? 
Untuk mengakhiri hubungan Yusril dengan Olivia, keluarga Yusril memutuskan uang jemputan sebesar Rp. 40.000.000,-. Berbagai cara dilakukan oleh Yusril untuk membantu Olivia menyanggupi uang jemputan tersebut, ia bahkan menjual mobilnya. Melihat keteguhan hati Yusril membuat Bagindo Sulaiman akhirnya menyetujui pilihan Yusril untuk menikah dengan Olivia.

\subsubsection{Konversi}

Konversi atau pemutarbalikan terjadi pada tokoh utama. Pada film JPAC tokoh etnis Tionghoa diperankan oleh seorang perempuan yaitu Olivia dan tokoh etnis Minangkabau diperankan oleh laki-laki yang bernama Yusril, lain halnya tokoh utama pada novel MR, tokoh Etnis Tionghoa diperankan oleh seorang laki-laki yang bernama Gunawan dan tokoh etnis Minangkabau diperankan oleh perempuan yang bernama Lela.

Tokoh perempuan pada kedua karya memiliki karakter yang berbeda dalam mempertahankan hubungannya dengan laki-laki yang berbeda etnis. Tokoh Olivia pada film JPAC dalam mempertahankan hubungan dengan Yusril tidak bisa berbuat banyak terhadap hubungannya karena kondisinya tidak memadai, terlebih lagi pada aspek materiilnya. Berbeda dengan Lela yang sangat memperjuangkan hubungannya meski ditentang keras oleh mamaknya Angku Datuk. Lela yang awalnya memiliki sikap ramah, sopan, dan sangat menghormati Angku Datuk menjadi seorang perempuan yang berani menentang larangan dan nasehat dari Angku Datuk demi mempertahankan hubungannya dengan Gunawan, hal ini terlihat pada kutipan berikut.

"Aku tak ingin bertemu dengan calonmu itu, Lela. Pokoknya aku anjurkan kau carilah calon lain."

"Kalau aku tidak mau?" jawabku berani.

"Aku tidak ikut acara lamar-melamar itu."

"Bagaimana kalau Angku ku pertemukan dengan calon uni Lela itu. Biar aku yang membawanya kesini menemui Angku," Ujar adikku mengusul.

Angku Datuk diam saja. Aku dapat menangkap rasa keberatan yang tergambar di wajahnya.

"Tidak perlu pertemuan itu. Nanti malah lebih gawat," kataku.

"Sebaiknya kau setujui saja, Lela," kata Etek Tangah. "Mungkin saja setelah pertemuan itu, pikiran Mak Datuk berubah, bukankah begitu yang baik, Mak?” katanya setuju pada kakak lakilakinya itu.

Angku Datuk masih tidak mau menjawab.

"Kalau Angku Datuk tidak setuju, aku tidak akan memaksa. Tapi jangan sesali aku, kalau nanti aku tidak akan berbicara lagi pada keluarga besar ini," ucapanku ingin mengakhiri pertemuan itu.

Tokoh laki-laki utama pada kedua karya ini juga memiliki karakter yang berbeda dalam mempertahankan hubungan percintaannya. Yusril memiliki sikap gigih dalam mempertahankan hubungannya dengan Olivia seperti halnya dengan Lela. Namun, Yusril menghadapi mamaknya tidak seperti yang dilakukan oleh Lela yang menentang keras bahkan mengancam mamaknya Angku Datuk. Yusril meluluhkan hati mamaknya dengan memperlihatkan kegigihan atas hubungannya kepada mamaknya Bagindo Sulaiman, dengan cara ini Bagindo Sulaiman menyetujui pilihan Yusril bahkan bersedia membiayai pernikahan mereka termasuk uang japuik. Hal ini sangat berbeda dengan novel MR, di mana mamak Lela Angku Datuk tetap tidak merestui hubungan Lela dengan Gunawan sampai akhir cerita.

Peran tokoh Gunawan (novel) dalam mempertahankan hubungannya dengan Lela tidak begitu terlihat, ia tidak berusaha menemui mamak Lela Angku Datuk untuk meminta persetujuan atas keinginannya memiliki Lela. Bahkan keluarga pada pihak ibu Gunawan pun tidak berusaha menemui Angku Datuk untuk melakukan 
mediasi ataupun semacamnya. Jadi, dapat disimpulkan tokoh etnis Minangkabau pada kedua karya memiliki peran lebih (kegigihan) dalam mempertahankan hubungan percintaannya.

Konversi pada keadaan tokoh utama terjadi pada tokoh Etnis Tionghoa dalam film digambarkan memiliki kehidupan yang sangat sederhana sedangkan tokoh Etnis Tionghoa pada novel MR merupakan seorang pengusaha sukses dan kaya. Tokoh etnis Minangkabau pada film digambarkan sebagai keluarga yang berkecukupan sedangkan seorang Dokter dan tokoh etnis Minangkabau pada novel MR merupakan seorang guru yang memiliki kehidupan yang berkecukupan. Dengan perbedaan finansial ini membuat permasalahan yang dihadapi pun berbeda.

Konversi juga terdapat pada cara tokoh utama dalam menghadapi penolakan mamaknya. Yusril menyelesaikan masalahnya sesuai dengan pepatah Minangkabau manitih ka pangka padang, artinya ia mencari titik lemah mamaknya dengan cara memperlihatkan kegigihannya untuk mendapatkan Olivia. Hal ini berbeda dengan yang dilakukan Lela dalam novel MR, ia bersikeras dengan dasar pikirannya dan menentang penolakan Angku Datuk, sehingga hubungannya dengan Angku Datuk tidak membaik hingga akhir cerita. Perilaku Lela ini tidak sesuai dengan mamangan adat orang Minang kamanakan barajo ka mamak, mamak barajo ka panghulu, panghulu barajo ka mufakat, mufakat barajo ka nan bana, nan bana badiri sandirinyo. Dalam hal ini perilaku Lela tidak bisa disalahkan, karena terjadinya ketimpangan dalam struktur matrilineal keluarga Lela dengan tidak adanya penghulu kaum dan menyebabkan Angku Datuk mengambil keputusan secara otoriter tanpa didasarkan mufakat.

\subsubsection{Modifikasi}

Modifikasi terdapat dalam tataran tempat dan waktu. Secara umum tempat peristiwa pada kedua karya ini yaitu Kota Padang, Sumatra Barat tepatnya di daerah Pondok. Namun, yang menjadi perbedaan tataran tempat pada kedua karya ini yaitu kampung halaman dari tokoh utama etnis Minangkabau. Kampung halaman Yusril tokoh utama pada film JPAC yaitu Pariaman, berikut penjelasan pada film.

Setelah mengantarkan Ana, Yusril menjemput Olivia. Di mobil....

Yusril: Pia, marapulainya orang mana?

Olivia: Pariaman, $u d a .$. kalau boleh Pia tahu $u d a$ sendiri orang mana?

Yusril: Orang Pariaman

Olivia: Pariaman??

Yusril: Seperti Pia kaget mendengar orang Pariaman

Olivia: Gak ... gak kok

Yusril: Oooh.. atau Pia keberatan punya teman orang Pariaman?

Olivia: Tidak, cumaaa tadiiiii.

Kampung halaman Lela yaitu Desa Sari Bulan, Kecamatan Matur, Kabupaten Agam, hal ini ditunjukkan pada kutipan berikut.

Sembilan bulan kemudian, anak ketigaku lahir, seorang perempuan. Kami beri dia nama Sari Bulan, lengkapnya Sari Bulan Gunawan Putri. Sebuah nama yang mengingatkanku pada nama kampungku, yang selalu ada di hatiku. Tempat aku mengurai rindu, rindu mandi di pancuran yang airnya jernih, rindu main di sawah ketika padi mulai menguning (Syamsuddin, 2012)

Perbedaan kampung halaman dari kedua tokoh utama ini menyebabkan konflik adat yang berbeda, di mana pada film JPAC Yusril dan pasangannya menghadapi adat uang jemputan yang berlaku di Pariaman, 
sedangkan Lela pada novel MR dihadapkan dengan permasalahan tentang mempertahankan harta pusaka tinggi (Rumah Gadang dan gelar pusaka) yang sangat dibanggakan oleh mamaknya Angku Datuk.

Ekserp terdapat pada penyadapan tema yang dikembangkan pada novel MR. Film JPAC dan novel MR mengangkat tema tentang perkawinan lintas budaya antara etnis Minangkabau dengan etnis Tionghoa. Kedua karya ini menginterpretasikan perjuangan pasangan kekasih dalam mempertahankan hubungan cinta mereka yang mengalami penolakan karena perbedaan etnis.

\section{PENUTUP}

Dari analisis yang peneliti lakukan dapat disimpulkan bahwa film Jangan Panggil Aku Cina merupakan teks hipogram dari novel Mengurai Rindu. Intertekstualitas keduanya terdapat dalam empat aspek yaitu ekspansi, konversi, modifikasi, dan ekserp.

Ekspansi terdapat pada konflik, tokoh, dan keadaan tokoh. Novel Mengurai Rindu mengekspansi konflik yang ada pada film Jangan Panggil Aku Cina. Konflik diperluas pada novel Mengurai Rindu mengenai konflik antara Lela dengan mamaknya Angku Sutan. Ekspansi pada tokoh terjadi pada novel Mengurai Rindu di mana keluarga tokoh utama dijabarkan secara detail, baik dari keluarga tokoh Gunawan maupun keluarga Lela. Selain itu ekspansi terdapat pada kehadiran dua orang mamak yang dimiliki oleh tokoh utama pada novel Mengurai Rindu. Selain itu, novel Mengurai Rindu mengekspansi keadaan tokoh dalam film Jangan Panggil Aku Cina. Perluasan keadaan tokoh terjadi pada tokoh Gunawan yang merupakan campuran dari etnis Tinghoa dan etnis Minangkabau.

Konversi terdapat pada pemeran tokoh etnis Minang dan Etnis Tionghoa. Pada film Jangan Panggil Aku Cina tokoh etnis Tionghoa diperankan oleh seorang perempuan dan tokoh etnis Minangkabau diperankan oleh laki-laki, pada novel Mengurai Rindu terjadi pemutarbalikan. Pemutarbalikan juga terdapat pada keadaan status sosial tokoh utama. Modifikasi atau perubahan terdapat pada novel Mengurai Rindu tentang penolakan mamak Lela atas calon suaminya. Lela tetap menikah dengan pemuda keturunan Tionghoa tanpa persetujuan mamaknya Angku Datuk. Modifikasi juga terdapat pada cara tokoh utama dalam menghadapi penolakan mamaknya. Ekserp terdapat pada penyadapan tema yang dikembangkan pada novel Mengurai Rindu. Tema yang diusung kedua karya ini yaitu perkawinan antar etnis Minangkabau dengan Tionghoa.

\section{DAFTAR PUSTAKA}

Asmaniar, A. (2018). PERKAWINAN ADAT MINANGKABAU. BINAMULIA HUKUM, 7(2), 131-140. Retrieved from http://fh-unkris.com/journal/index.php/binamulia/article/view/23

Elvia, R., Anwar, K., \& Meigalia, E. (2018). MAMAK DAN UANG JEMPUTAN DALAM NOVEL MAHAR CINTA GANDORIAH - MAMAK AND UANG JEMPUTAN IN MAHAR CINTA GANDORIAH. Jurnal Elektronik WACANA ETNIK, 7(1).

Endraswara, S. (2003). Metode Penelitian Sastra: Epistemologi, Model, Teori, dan Aplikasi. Yogyakarta: FBS UNY.

Oktavia, N. A. (2011). Tradisi Uang Jemputan dan Uang Hilang di Kabupaten Padang Pariaman dalam Novel Ketika Rembulan Bernyanyi : Tinjauan Sosiologi Sastra. Universitas Andalas.

Putra, R. Z. (2016). Tradisi Uang Japuik dan Status Sosial Laki-Laki. Fakultas Syariah dan Hukum UIN Syarif Hidayatullah Jakarta, Jakarta. Retrieved from http://repository.uinjkt.ac.id/dspace/handle/123456789/32944

Sudikan, S. Y. (2001). Metode Penelitian Sastra Lisan. Surabaya: Citra Wacana. 
Jurnal Elektronik WACANA ETNIK - Vol 7 No 2 Oktober 2019, (99 - 107) p ISSN 2089-8746, e ISSN 2302-7142

Syamsuddin, N. (2012). Mengurai Rindu. Yogyakarta: Rahima Intermedia Publishing. Teeuw, A. (1993). Membaca dan Menilai Sastra. Jakarta: Gramedia. 